THE CANADIAN JOURNAL OF AUTISM EQUITY LA REVUE CANADIENNE DE L'ÉQUITÉ EN MATIÈRE D'AUTISME \begin{tabular}{l|l|l} 
VOLUME 1 & ISSUE 1 & APRIL 2021
\end{tabular}

\title{
Nothing to Bragg About: Examining the Search for Autistic Representation in History
}

Cameron Winter, Wilfrid Laurier University, Canada

RECOMMENDED CITATION: Winter, C. (2021). Nothing to Bragg About: Examining the Search for Autistic Representation in History. The Canadian Journal of Autism Equity, 1(1), $55-61$. 
CANADIAN JOURNAL

OF AUTISM EQUITY

REVUE CANADIENNE DE L'ÉQUITÉ

EN MATIĖRE D'AUTISME

\title{
Nothing to Bragg About: Examining the Search for Autistic Representation in History
}

\author{
By Cameron Winter
}

\begin{abstract}
Using the career of infamous Confederate General Braxton Bragg as a case study, this article poses questions about how we search for and discuss possible examples of Autistic people in history. The article contends that we need to reconsider what we hope to accomplish when posthumously diagnosing historical figures and the way in which those discussions are structured, cautioning against both the hunt for role models and the tendency towards defining people by their disability.

Résumé

En utilisant la carrière du tristement célèbre général confédéré Braxton Bragg comme étude de cas, cet article s'interroge sur la façon dont nous recherchons et discutons des exemples possibles de personnes autistes dans

l'histoire. L'article soutient que nous devons reconsidérer ce que nous espérons accomplir lorsque nous diagnostiquons des figures historiques à titre posthume, ainsi que la façon dont ces discussions sont structurées, en évitant le piège de chercher à trouver des modèles d'identification et la tendance à définir les gens par leur handicap.
\end{abstract}

Keywords

Autism, history of neurodiversity, Braxton Bragg, American Civil War Mots clés

Autisme, histoire de la neurodiversité, Braxton Bragg, guerre civile américaine

1 Wilfrid Laurier University, Canada 
Early in 1863 , following his repulse at the Battle of Stones River, Confederate General Braxton Bragg, in a move that has baffled historians to this day, circulated a letter to his subordinates. In it, Bragg inquired as to whether his generals agreed with his recent decision to retreat, ending with an offhanded remark about how he was prepared to resign if they did not. The response he received was unanimous and, to Bragg, infuriating: his sub-commanders thought Bragg had been entirely correct to retreat and that he should resign anyway because none of them had any confidence in him. Viewing this as an attack on his person, Bragg stayed on to spite his critics, creating a toxic atmosphere at headquarters that, in the view of many historians, thoroughly poisoned the ability of the Army of Tennessee to function in future battles (Hess, 2016, p. 136-137).

The root of the discord between Bragg and his officers lay in the wording of his letter. Bragg believed he had asked them a single question, regarding whether the retreat had been a mistake,

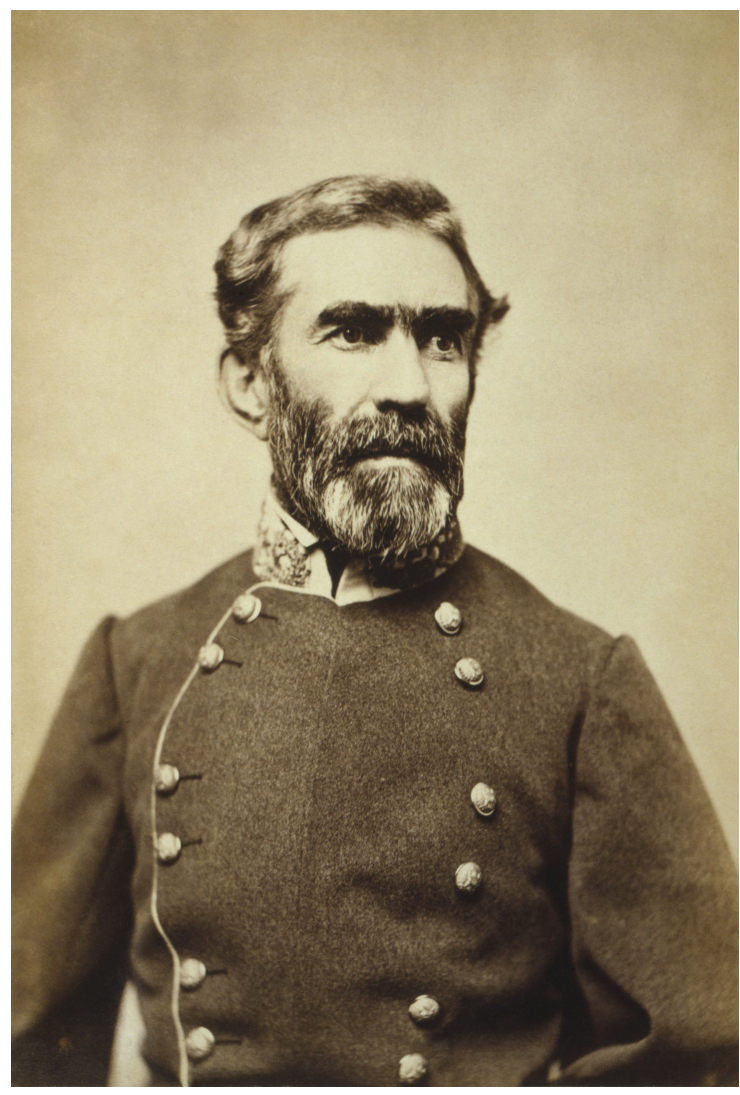

Figure 1. Gen. Braxton Bragg Note. By Unknown author, restoration by Adam Cuerden, Wikipedia https://upload.wikimedia.org/wikipedia/ commons/6/6e/Braxton_Bragg.jpg with his resignation being offered if they believed that it was. Bragg's letter, however, phrased this not as a question and an offered solution, but rather as two separate questions. They answered both, and in doing so, permanently ruined their relationship with Bragg; the rigidminded General's good opinion, once lost, being impossible to regain. Bragg's future campaigns against Chickamauga and Chattanooga, unsurprisingly, foundered on this undercurrent of ill-will between him and his subordinates, an ill-will that historians have spent the better part of a century and a half trying to untangle (Hess, 2016, p. 136-137). Perhaps they have been searching for answers in the wrong places: given Bragg's many eccentricities and personal quirks, the explanation for what happened after Stones River may lie not in Bragg's external relationships, but within the General's own mind.

This certainly was not the first or last time the socially inept Bragg landed himself in hot water. Described by contemporaries and historians as austere, aloof, dyspeptic, and a martinet, Bragg was infamous for his inability to get along with any of the men he served with and left a trail of bruised feelings and bitter recriminations wherever he went. ${ }^{2}$ Moody, sarcastic, and apparently oblivious to the feelings of others, Bragg caused a minor scandal when he referred to one of his

2 Hess' preface (pages xii through $\mathrm{xx}$ ) offers a thorough look at what historians have traditionally said about Bragg, and the primary sources they have drawn on to do so. 
divisional commanders as a "useless old woman," in front of his staff, and offended junior officers serving under him by refusing to speak to them in person, communicating only through his staff officers (Hess, 2016, p. xiii). Not every personality conflict was Bragg's faultfew generals managed to get along with blustering Leonidas Polk and psychopathic Nathan Bedford Forrest, who were among his most vociferous critics-but Bragg's lack of social tact and inability to gauge the impact of his words also destroyed his relationships with men who had once been his friends. ${ }^{3}$ Corps commander Thomas Hindman, once a strong supporter of Bragg, turned against him after Bragg dressed him down in front of his men (Cozzens, 1994, p. 86). Bragg's fulminations against the treacherous nature of Kentuckians after a failed campaign in that state persuaded Kentucky officer John Breckinridge, whom Bragg had specifically requested for his army, that the General was plotting to have him, and all the other Kentuckians in the army, killed (Cozzens, 1991, p. 52). Bragg, for his part, was mystified by Hindman and Breckinridge's sudden dislike for him, apparently unable to connect the dots between the things he had said and their changed attitudes.

Bragg's obsessive rule-following and literal mindedness did not make his life any easier. Going back to his days as a junior officer, Bragg regularly fell out with his superiors when he questioned their decisions or objected to their refusal to enforce discipline to the standards set out in the army guidelines. On one occasion, when a reporter made a joke about Bragg's native North Carolina not being a real state, Bragg challenged him to a duel, not because of the insult to his state, but because he took the joke literally and truly thought the man was denying its existence; when the reporter altered his statement to say that North Carolina existed but was terrible, Bragg backed down (Hess, 2016, p. 3). During the Civil War, Bragg earned the hatred of his men when he executed a soldier for murdering a Black civilian, something few other officers in the Confederate Army (who were, after all, fighting to keep African-Americans in bondage) would have done. To Bragg, however, the decision was clear: the man had violated the rules of war, and had to be shot, impact on morale and Bragg's own reputation be damned (Hess, 2016, 44-45). 4

Union General-in-Chief, Ulysses S. Grant, who opposed Bragg at the Battles of Chickamauga and Chattanooga, recalled in his memoirs a story he had heard that well-encapsulated how the socially awkward Bragg was viewed by his peers. Doing double duty as a fort's quartermaster and the captain of one of the companies defending it, Bragg, as company commander, put in a request for supplies, and as quartermaster, denied it. As company commander Bragg then appealed the denial, and as quartermaster he fought the appeal. Unable to work out this conflict of interest on his own, but also unwilling to ask for help through normal channels, Bragg referred the matter to the fort commander, who on becoming aware of the situation exclaimed: "My God, Mr. Bragg, you

\footnotetext{
3 David A. Powell's (2016) Failure in the Saddle argues, fairly convincingly, that Bragg was signally ill-served by his cavalry commanders, specifically the malcontented Forrest and the incompetent Joseph Wheeler, whose dislike of one another damaged the Army of Tennessee almost as much as Forrest's distaste for Bragg.

4 Hess' own neo-Confederate sympathies shine through here when he describes the killing of a Black civilian as a "trivial reason" to execute a soldier, and tries to prove, unconvincingly, that the execution was for killing a pig, with Bragg relenting at the last moment and letting the man go.
} 
have quarrelled with every officer in the army, and now you are quarrelling with yourself!" Grant admitted he did not know if the story was true, but he definitely thought it sounded like Bragg, and that was damning in and of itself (Grant, 2017, p. 450). ${ }^{5}$

The tragedy of all this, at least from the Confederate view, was that Bragg was not an unintelligent officer. He came up with excellent plans: yet again and again, his inability to get along with his subordinates, or to communicate his intentions to them, sabotaged his schemes. At Stones River, Bragg executed a brilliant turning maneuver that wrecked Union Major-General William Rosecrans' vanguard, but also thoroughly disrupted his own chain of command until orders became impossible to relay and the offensive broke down (see Cozzens, 1991, for the best existing analysis of what went wrong at Stones River). The same problems bedevilled him at Chickamauga and Chattanooga, with Bragg insisting his officers were disobeying his instructions, while they swore Bragg never made his intentions clear (see Cozzens, 1996, 1994, respectively). Bragg himself was at least dimly aware of his issues on this front, and in his letters to his wife bemoaned the fact that she was the only one who had ever truly understood him and expressed a wish that he could talk to other people as easily as he did her. Said Lieutenant-Colonel Archer Anderson, who served under Bragg for much of the war, "General Bragg seemed to know always what ought to be done, to possess the decision and the will to order it to be done, but, by some strange lack of gift, where so many gifts abounded, he could not do it himself and he could not make others do it" (Cozzens, 1994, p. 17). Depending on which historians one asks, Bragg's failures to manage his officers lost the Confederacy the Civil War in the West and helped bring about the end of the secessionist project, and with it, slavery in the United States.

Clearly, Braxton Bragg's communication difficulties were of considerable import to the history of the United States. Yet the source of those difficulties has tended to go unexamined beyond general commentary on Bragg's acerbic personality. That Bragg was, in some fashion, socially handicapped, is not really in question: his problems talking to subordinates and superiors are a matter of public record while his mercurial emotions and episodes of depression were commented on by all who knew him. Yet no one, at least to this author's knowledge, seems to have asked the following question: was Bragg's handicap literal as opposed to figurative? Was the Confederate high command failing to accommodate a neurodivergent general at a time when terms like "neurodivergent" had yet to be invented? Put more bluntly, was Braxton Bragg Autistic?

It is an impossible question to answer with certainty, but the evidence does seem to be there, especially when contrasted with other historical characters who are assumed to be on the spectrum. Figures like Sir Isaac Newton and Albert Einstein have been diagnosed, in the popular consciousness at least, on the basis of the details of their personal lives and little more. Bragg, however, as the leader of an army, left behind a vast body of primary sources in the form of orders, courts-martial transcripts, minutes of meetings, his own correspondence, and the

\footnotetext{
5 Hess contends the anecdote is entirely untrue; other historians take it at face value. This article offers no opinion on its accuracy but believes the story does demonstrate how Bragg was seen in the eyes of others.
} 
correspondence, official and unofficial, of the subordinates, superiors, political masters, and even enemies, who had to deal with him. Anyone interested in tracking the rise and fall of an Autistic general could easily comb through those sources for evidence, yet no one has. The Autistic community, eager to claim men like Newton and Einstein, has not sought to claim Braxton Bragg, despite the ease with which it might be done. The question then needs to be asked: why is that?

Obviously, Bragg is not a household name in the way that Newton and Einstein (or Civil War contemporaries like Grant and Robert E. Lee) are. For those wishing to communicate with as wide an audience as possible, the urge-and perhaps the need-to draw on examples that their audience is already familiar with will always be there. Yet at the same time, Bragg is hardly an obscure figure, either. Anyone who reads about the American Civil War-a perennially popular topic not only within the United States, but without it-will quickly come across Bragg, and, soon after, the myriad interpersonal dramas in which he embroiled himself. Until just recently, a US military base, Fort Bragg, bore his name, and many landmarks below the Mason-Dixon line still do. Moreover, the case for Bragg being on the spectrum is easy enough to make that one might expect it would more than compensate for his comparative lack of fame. What else, then, is at work here?

The fact that Braxton Bragg makes a poor role model may be one of the factors telling against him. A traitor to the United States and a devoted proponent of slavery, Bragg was a bad officer and a worse man, and can hardly be held up as an Autistic success story the way that a Newton or an Einstein, who, whatever their personal failings, are generally well-regarded by the public, can. Even those who are morally dubious enough to offer apologetics for the Confederacy, are unlikely to sympathize with Bragg. A recent biography was entitled The Most Hated Man of the Confederacy, and it did not exaggerate; Bragg's reputation as a thoroughly unpleasant human being defines his legacy and his portrayal in most historical works (Hess, 2016). That reputation is a turnoff even for most dedicated historians of the Civil War, and it is not hard at all to imagine circumstances in which historians of autism, searching the history books for examples, came to the entry on "Bragg, Braxton," and after a brief perusal, quickly turned away.

An argument could even be made that, if Bragg was Autistic, we have an obligation not to talk about it for fear of poisoning the public against people on the spectrum. A reading of Bragg's papers does, after all, make it apparent that his support for slavery stemmed from the institution enabling him to run his planation without having to negotiate with, or even communicate with, his workers, something the socially anxious North Carolinian found a tremendous relief (Hess, 2016, p. 10-12). A sufficiently bad faith actor might use that to contend that Bragg was a slaver, and subsequently, a traitor, because he was Autistic, and using that information, paint all Autistic persons with as broad and black a brush as can be imagined. Bragg's demonstrated incompetence in high command would only add to that case, presenting a very unflattering portrait indeed of those of us on the spectrum.

Yet such a portrayal of Bragg would, unfortunately, be the logical inversion of the hunt for role models. While there is nothing inherently wrong with saying "Isaac Newton was probably 
Autistic" in an effort to reduce the stigma against the disorder, it can, and often does, go wrong when diagnosis is treated as destiny. While our society has made significant strides in how we discuss physically disabled historical figures (few people would, for instance, define Franklin Roosevelt by his inability to walk), the same cannot be said for those we suspect to have been psychologically different. Too often, the author has encountered people who not only assume that Newton, Einstein, or pick-your-scientific-genius was on the spectrum, but that their genius stemmed from their being on the spectrum, a form of positive stereotyping that nevertheless reduces these men (and they are almost always men) to being the sum of a diagnosis that they may or may not have had. This kind of thinking, however well-intentioned, is lazy and ableist when applied to an Isaac Newton, and becomes ugly to the point of repulsion when applied to a Braxton Bragg, as demonstrated in the paragraph above. This in turn condemns figures like Bragg to remain undiscussed when talking about neurodiversity in history, in the hopes that we can avoid giving ideas to those with malignant intentions.

This is a shame, because our goal in talking about autism in history should be about more than just the quest for role models. It should be about the lived experience of having an invisible disability at different periods in history, and Braxton Bragg, and others like him, could be an invaluable part of that conversation. It should also be about reminding the public that autism and other forms of neurodivergency are not new, and are not the product of modern society, or vaccines, or whatever other pseudoscientific ideas the Internet seeks to push on us. Braxton Bragg may have been an inveterate jackass, but he did not get that way because of a measles vaccination, and when it comes to pushing back against conspiracy theories, he serves as effective an example as any. He might even be a better example than some of the role models mentioned above, for while the behaviour of a Newton or Einstein might be possible to write off as the eccentricity of a successful man, Bragg's career-damaging faux pas are much more difficult to ignore-and are attested to in official government documentation.

Moving beyond questions of incorporating these historical figures into the modern quest for social justice, every potential example we can uncover also allows us to ask questions about the society they hailed from. Assuming that Isaac Newton was on the spectrum, what was it about the scientific community in his day and age that enabled him to be as successful as he was? In what ways did his neurodivergence help him? In what ways did it hinder him? The same questions can just as easily be asked about Bragg. What was it about the Confederate hierarchy that enabled Bragg to rise as high as he did and to maintain his position for so long as he did, yet prevented him from achieving success while he was there? Why did Confederate President Jefferson Davis, the ultimate arbiter when it came to military commissions, keep Bragg on even as the personal scuffles between him and his subordinates mounted, and was Davis' judgement as poor as has often been assumed? It would only be justice to Bragg to, at this juncture, note that Davis did eventually find a post that suited the cantankerous general better than field command. This was as Davis' personal military advisor, and de facto chief-of-staff and inspector-general of the Confederate Army. Put in a position involving hard numbers and that limited the number of individuals he had to deal with, Braxton Bragg made real contributions to the last year of the Confederate war effort, imposing order on a supply system that had been heading for 
disintegration (Hess, 2016, p. 241). What was it that allowed Bragg to do that, and was it linked to the same mindset that made riding herd on his underlings so impossible for him? Were there other figures in the Confederate-and for that matter, the Union-ranks like him, and if so, how similar were their experiences, and what do those experiences say about their respective armies?

This article is not meant to conclusively argue that Braxton Bragg was on the autism spectrum, one hundred percent guaranteed. Such an undertaking would be impossible. Rather, it aims to question the ways in which we discuss the history of autism, and, more broadly, neurodivergence and disability. Some historians believe that psychoanalyzing the past is a waste of time. The author does not share that opinion. We should, however, consider at all times our own motivations in doing so, and ask what, precisely, we are hoping to prove. Neurodiversity deserves a place in the historical conversation, but determinists and those who only play with history in hopes of finding "good role models" need not apply.

\section{References}

Cozzens, P. (1991). No Better Place to Die: The Battle of Stones River. University of Illinois Press.

Cozzens, P. (1996). The Shipwreck of Their Hopes: The Battles for Chattanooga. University of Illinois Press. Cozzens, P. (1994). This Terrible Sound: The Battle of Chickamauga. University of Illinois Press.

Grant, U. S. (2017). The Personal Memoirs of Ulysses S. Grant: The Complete Annotated Edition (J. F. Marszalek, D. S. Nolen, and L. P. Gallo, Ed.). The Belknap Press of the Harvard University Press.

Hess, E. J. (2016). Braxton Bragg: The Most Hated Man of the Confederacy. The University of North Carolina Press.

Powell, D. A. (2010). Failure in the Saddle. Savas Beatie LLC. 